\title{
Yerel Bağlamsallığın Soylulaştırma Üzerine Etkileri: Turizm Soylulaştırmasında Nevşehir Uçhisar*
}

\author{
Tuğçe Utku ${ }^{1}$ \\ ORCID: 0000-0002-7156-6728
}

*

\author{
Zeynep Uludağ 2 \\ ORCID: 0000-0001-9242-7957
}

Öz

Çalışmada kentlerde, dönüşüm sürecinin temel araçlarından biri olarak görülen soylulaştırma kavramı bu süreci etkileyen/direnç gösteren yerel dinamikleri çerçevesinde Nevşehir'in Uçhisar ilçesi odağında ele alınmıştır. Literatürde soylulaştırma sürecinin çoğunlukla olumsuz algısına odaklanan çalışmalarm aksine, bu kavram, kentsel ve kuramsal bağlamda çoğulcu-bütüncül bir yaklaşım prensibi gösterilerek, yerel farklılıkları gözetecek biçimde turizm bileşeni ile yeniden düşünülmüştür. Bu çerçevede çalışma, soylulaştırma kavramının yönünü, 'turizm soylulaştırması'na çevirmiştir. Disiplinler arası boyutlarıla, son dönemde Kapadokya'nın hem turizmiyle hem de turizmin getirisini arttırmak amact ile yapılan kentsel müdahalelerle Nevşehir'in gelişen yüzü olarak görünen Uçhisar beldesine ait yerel dinamiklerin soylulaşma(ma) üzerindeki etkisi araştırılmıştır. Bölge olarak Uçhisar'ın nirengi noktası olan Uçhisar Kalesi çevresi seçilmiştir. Yöntem olarak fiziksel değişimin yerinde gözlemlerle incelendiği çalışmada kale etrafinda halen konut olarak kullanılan bölgede konut sakinleriyle yarı yapılandırılmış görüşmeler yapılmıştır. Verilerin değerlendirilmesiyle, kentlerin önemli gündemi olan soylulaştırmanın parametrelerinin yerel bă̆lamsal özelliklere bağh olduğu görülmüştür. Uçhisar gibi kırsal özelliklere sahip bir bölgenin turizmle beraber dönüşüm sürecinde yaşadıklarının soylulaştırmayı oluşturma(ma) sürecinde ne gibi yerel etkileri olduğu ortaya çıkarılmıştır. Çalışma, soylulaştırmanın yerel bağlamsallık ilişkisini göz önüne serdiği için aslında konunun ne kadar genelleştirilemez ve yerel değerlerin de ne kadar yadsinamaz olduğunu açıklamakla beraber, benzer turizm süreçlerinden geçen kent parçaları için soylulaştırmayı engelleyebilecek parametrelere de ulaşılmasını sağlamaktadır.

Anahtar Kelimeler: Soylulaştırma, turizm soylulaştırması, Uçhisar, kentsel yenileme, yerel bağlamsallık.

\footnotetext{
* Bu makale çalışması “5.Kent Araştırmaları Kongresi”nde bidiri olarak sunulmuştur.

${ }^{1}$ Arş. Gör., Atılım Üniversitesi, E-mail: utkutugce@gmail.com

2 Prof. Dr., Gazi Üniversitesi, E-mail: uzeynep@gazi.edu.tr

idealkent @ C Kent Araştırmaları Dergisi (Journal of Urban Studies) 


\title{
Effects of Contextualization on Gentrification: Nevşehir Uçhisar in Tourism Gentrification
}

\author{
Tuğçe Utku ${ }^{3}$ \\ ORCID: 0000-0002-7156-6728
}

\author{
Zeynep Uludağ 4 \\ ORCID: 0000-0001-9242-7957
}

\begin{abstract}
In the study, the concept of gentrification, which is seen as one of the basic tools of the transformation process in cities, has been discussed in the focus of Uçhisar district of Nevşehir within the framework of local dynamics that affect / resist this process. Contrary to the studies in the literature that mostly focused on the negative perception of the gentrification process, this concept has been reconsidered with the tourism component in a way to takes into account local differences, demonstrating the principle of pluralistic and holistic approach in urban and theoretical contexts. Within this framework, the study has directed the gentrification concept to "tourism gentrification". With its interdisciplinary dimensions, the effect of local dynamics of Uçhisar town, which is seen as the developing face of Nevşehir, with the urban interventions to increase both tourism and the return of tourism in Cappadocia, on gentrification has been investigated. The surround of Uçhisar Castle, which is the landmark of Uçhisar, has been chosen as the fieldwork. As a method, in the study where physical change was examined through on-site observations, semi-structured interviews were made with the residents of the area around the castle, which is still used as a residence. By evaluating the data, it was seen that the parameters of gentrification, which is the important agenda of the cities, depend on local contextual characteristics. What kind of local effects the experiences of a rural region like Uçhisar in the transformation process with tourism in the process of creating gentrification have been revealed. Since the study reveals the local contextuality relationship of gentrification, it explains how indispensable the subject is and how indisputable local values are, but also provides access to parameters that can prevent gentrification for urban parts that have gone through similar tourism processes.
\end{abstract}

Keywords Gentrification, tourism gentrification, Uçhisar, urban regeneration, local contextuality

\footnotetext{
${ }^{3}$ Arş. Gör., Atılım Üniversitesi, E-mail: utkutugce@gmail.com

${ }^{4}$ Prof. Dr., Gazi Üniversitesi, E-mail: uzeynep@gazi.edu.tr

idealkent @ C Kent Araştırmaları Dergisi (Journal of Urban Studies)

http://idealkentdergisi.com
}

Geliş Tarihi Received Date: 23.10.2020 Kabul Tarihi Accepted Date: 15.04.2021 


\section{Giriş}

Dünyada 1960'larda tartışlan, Türkiye'de ise 1980'lerde somut örneklerinin görüldüğü soylulaştırma kavramı, fiziksel dönüşümlerin yarattığı mimari kimliklerde ve sosyal ortamda oluşan farklılıkların vurgulandığı kaotik bir durumdur. Ortaya çıkışından günümüze, ilk söylendiği şekliyle temel alınsa da farklı birçok tanımı yapılmıştır. Sınıf ve devlet çerçeveli bir bakış açısıyla bakıldığında orta sınıfların işçi sınıflarını yerinden ederek sınıflar arası kutuplaşmayı artıran bir süreç olarak görünürken, işlevsel bir bakış açısıyla, farklı sınıfların bir arada yaşadığı veya yaşayamadığı, konuta dair tercihlerin vurgulandığı, yıllarca bakımsız kalan tarihi olan/olmayan yapı stokunun korunmasını ve bakımını vurgulayan bir durum olarak görünmektedir. Yakın zamanda soylulaştırma ile ilgili yapılan çalışmalara bakıldığında, kavramın ilk ortaya çıktığı kentlerdeki durumu göz önüne alınarak, farklı kentlerde aynı sürecin yaşandığı, hatta aynı özelliklerle bir "soylulaştırma genellemesi"nin ortaya çıtığı anlaşılmaktadır. Ancak bu tür bir soylulaştırma anlayışının, farklı kentlerde görülen soylulaştırmanın bağlamsal çeşitliliğini, özelliklerini ve/veya varsa sınırlarını gölgelemekte olduğu görülmüş̧ür.

Disiplinler arası bir araştırma alanı olarak görülen soylulaştırma kavramının akademik yazında, sosyolojik çalışmalara kıyasla mimarlık ve kent odaklı bağlantılarının henüz yeterince konu edinmediği görülmüştür. Kentlerde ve son dönemlerde kırsal alanlarda oluşan soylulaştırma durumunu belirleyen unsurların, kentlerin ya da beldelerin kendine özgü gelişim kriterleriyle örtüşmeyecek bir şekilde konvansiyonel olarak kabul edilmesi, konunun daha derin ve geniş bir bakış açısıyla incelenmesi gereğini doğurmuştur. Smith' in (2006, s.27) vurguladığı "Herhangi bir kenttekilyerdeki soylulaştırma süreci kendi yerel- kentsel mekanın yaratmada kendi özelliklerini yansıtmaktadır." görüşü ile, soylulaştırmanın "yerel dinamiklerini" araştırmak ve bağlamsallığını ortaya koymak çalışmanın temel hedefini oluşturmaktadır.

Literatürde ilk ortaya çıan soylulaştırma tanımı 1964 yılında sosyolog Ruth Glass tarafından London: Aspects of Change isimli çalışmasında Londra'nın dışında (banliyölerde) yaşayan ve kent merkezinde yaşamayı seçen orta sınıfın, tarihi Viktoryan tarzı işçi konutlarına yerleşerek bu alanları yenilemesi ve mevcut kullanıcıyı yerinden etmesi şeklinde olmuştur (Glass, 2010, s.27). Akademik çalışmalar incelendiğinde hem Glass'ın tanımının günümüze kadar değişmesi, hem de yapı türü olarak farklı yapı 
çevrelerini etkilemesi bakımından kavramsallaştırma çalışmalarının sonu gelmeyen ve dönüşen bir boyut kazandığ 1 açıtır. Tanımlarında çoğunlukla çeşitliliği gölgeleyen bu kavramın, bazı temel benzerlikleri de mevcuttur: işçi sınıfı, yer değiştirme süreci, sürecin bir tek kent merkezinde gerçekleşmesi, tarihi bölge olması, sınıfsal ayrımı vurgulaması vb. Başka bir deyişle kavramın öncüleriyle, aktörleriyle, süreciyle genelleştirilmesi mekanların veya alanların bağlamsal kimliğini göz ardı etmeye de sebep olmaktadır. Kavramın tanımlarının ileri sürdügü sınıf türleri, aktörler, öncüler (işçi sınıfı, orta üst sınıf, genç profesyoneller, sanatçılar vb.) bugün kentlerin yenilenmesi sürecinde çok daha farklı formlar almakta ve çoğu zaman bu formların yerel etkiler sonucu değiştiği gözlenmektedir. Bu nedenle soylulaştırmayı tetikleyen, sınırlayan yerel faktörlerin araştırılmasının literatürdeki soylulaştırma genellemelerinin yönünü değiştirmesi beklenmektedir.

Bu çalışma bahsi geçen değişimi, anglosakson soylulaştırma tanımlarını genişleterek soylulaştırmanın hem kesişim hem birleşim kümesinde var olan "turizm soylulaştırma"sı terimine odaklanarak yeni bir tartışma zemini oluşturmuştur. Bu sayede turizm yolu ile ortaya çıkan soylulaştırmaya eleştirel bir yaklaşım ortaya konurken, soylulaştırma süreci bağlamsallık üzerinden incelenmiştir. Soylulaştırma literatüründe süreci turizmle birlikte açıklayan ilk çalışmalardan biri Gotham'ın 2005 yılında ortaya çıardığı Tourism Gentrification: The Case of New Orleans' vieux carre isimli çalışmasıdır. Gotham (2005 s.1101), turizm soylulaştırmasını orta sınıf bir mahallenin, kurumsal eğlence ve turizm mekanlarının çoğalmasıyla, bölgenin nispeten zengin ve seçkin bir yerleşim yerine dönüşmesi üzerinden tanımlamaktadır.

Hızlı kentleşme sürecinde göz ardı edilen tarihi bölgelerin giderek çöküntüleşmesi sonucu bölgelerin sunduğu alternatif mekânsal çeşitlilik, yenilik, kurgu, doku vb. özelliklerle gelir bakımından daha yüksek kullanıcıların ilgisini çekmeye başlamıştır. Bu da karar vericiler tarafından kentlerin bu bölgelerinde turizm odaklı sağlıklaştırma, kentsel yenileme, kentsel canlandırma çatısı altında müdahalelerinin artmasına neden olmuştur. Bu anlamda tarihi çevreler kaybettikleri değerlere yeniden ulaşmaya başlamışken kullanıcı çeşitliliği de bir takım sınıf ayrımının izlerini ortaya çıkarmıştır. Kapitalizmin gelişim göstermesi ile kentlerde turizmin bölgesel rekabete girmenin bir aracı olarak kullanılması durumu, o yerlerde soylulaştırmanın ilerlemesine de olanak sağlamıştır (Gant, 2018, 
s.28). Klasik soylulaştırmada öncü gruplar turizm soylulaştırmasında turist sınıfı olarak tanımlanır ve Gant $(2018$, s.67) bir Avrupa kentinde yaptığ çilerin ve yerel halkın arasında hem mülk değerleri anlamında hem de alım gücü anlamında giderek artan bir gerilim oluştuğunu belirtir. Turistlerin bölgeye yeni bir "yaşam tarzı" getirmesi ile hem toplumsal hem de mekânsal gereklilikler açısından bölgede değişimlerin gerçekleşeceği belirtilmiştir. Bunun sonucunda alım gücü farkının yarattığı boşluk, yerel halk için giderek uygunsuzlaşan yerler haline gelen hem konut hem de diğer hizmet odaklı birimler üzerinde baskı yaratmaya başlamıştır. Çalışma çerçevesini bu düşünce ile sınırlayan bir soylulaştırmanın, yarattığ1 sosyolojik ve fiziksel etkiyi paralel bir şekilde analiz ederek kurmuştur.

Turizm soylulaştırmasının tanımı gereği mekânsal dönüşümün çoğunlukla turizm ve eğlence odaklı değişmesi ile mevcut mekanlarda bu yönde değişimler olacağ sektör girişimi ile müdahalelerin yapıldığı mekanlarda bir ticarileşme söz konusudur. Bir alan çalışması ile soylulaştırma olarak izlerinin analiz edildiği bölgede, ticarileşme boyutunda sosyo-mekansal etkisini de inceleyerek oluşan tüm faktörlerin soylulaşma süreci üzerindeki etkilerini, konunun yerel dinamiklerini ortaya çıkararak tartışmaktadır.

Yukarıda bahsedilen veriler Nevşehir iline bağlı ulusal ve uluslararası turizm anlamında kent ölçeğinde önemli katkılara sahip Uçhisar beldesi üzerinden incelenmiştir. Uçhisar, bulunduğu konum gereği Kapadokya bölgesinin giriş kapısı niteliğindedir. Sahip olduğu doğal zenginliklerin, ziyaretçisine sunmuş olduğu kültürel deneyim ile son dönemde bölge fiziksel ve toplumsal olarak pek çok gelişim göstermiştir. Özellikle açlan otellerin sayısının ve bu birimleri destekleyici diğer ticari birimlerin sayısının artması ile beldede yerli halk yerleşim yeri ve turizm odaklı yerleşim yerlerinin iç içe geçmeye başladığı hatta bununla kalmayıp yerleşimin giderek turizmin odağı haline geldiği görülmektedir. Bu durum, çalışmanın alan olarak bu bölgeyi seçmesinin önemli verilerinden biridir. Beldede bu iç içeliğin soylulaştırma sürecine etkisinin yerel dinamiklerle engellendiği veya soylulaştırma sürecinin yerleşime kattığ olumlu olumsuz durumların analiz edildiği çalışmada fiziksel ve toplumsal değişimi bir turizm kenti üzerinden, turizm-soylulaştırma ikilisi ile tartışmak, bölgede hane halkının turistlerle olan ilişkisini değerlendirmede de önemli veriler sunmuştur. 
Bölgede turizmin etkisine bağlı olarak gittikçe artan ziyaretçisi ile (soylulaştırma literatürüne göre öncüler veya aktörler) yerli konut sakinlerinin hem konut dinamikleri hem de mahalle yaşamındaki deneyimlerinin, herhangi bir yer değiştirme/ yerinden etme durumuna sebebiyet verip vermediğinin gözlenmesi de araştırmada bu bölgenin seçilmesindeki diğer önemli etkiler arasındadır. Bu bağlamda turistlerin kültür turizmi amacıyla bölgeye gelerek burada hareketli, etkin ancak kalıcı olmayan yeni bir sinıf oluşturmalarının yerel halk üzerindeki etkisi değerlendirilmiştir.

Öte yandan bölgede eski konut dokusunun restorasyonu ile otel birimlerine dönüşmesi, butik otellerin sayısının artışının da bölgede ticarileşme eğilimini etkilemesi bölgenin turizm soylulaştırması bağlamında araştırılacak potansiyelleri olduğunu göstermiştir. Araştırma, yapılı çevrede ziyaretçilerin hatta dönüşüm sonucu hitap ettiği kesim olan 'varlıklı kullanıcıların' taleplerini karşılayan ve/veya yerli halkın kalmasını zorlaştıran parametrelere direnmesini sağlayan, bir sermaye yatırım süreci olarak soylulaştırmanın bağlamsal dinamiklere bağlı tanımının yapılmasına olanak sağlamaktadır.

Çalışmada kent parçalarında turizm ile ortaya çıan fiziksel ve sosyal değişimin net bir şekilde okunabildiği ancak bununla beraber sosyal çevre üzerinde olumsuz etkiler yaratarak yer değiştirmeye ve kullanıcı üzerinde gerek ticari gerek yaşamsal baskılar oluşturabilecek soylulaştırma durumunun mercek altına alınmıştır. Bunun yanında aslında mimari biçimin turizmle nasıl değiştiği ortaya çıkarılırken, analizler Uçhisar'da lokal özelliklerin soylulaşmanın yerel dinamiklerine yönelik yapılmıştır. Bunun için yöntem olarak turizm amaçlı faaliyet gösteren otellerin giderek artış gösterdiği Uçhisar eski yerleşim bölgesi olan kale çevresinin fiziksel değişimi yerinde gözlemler yapılarak incelenmiştir. Kale etrafında artan otellerin arasında halen konut olarak kullanım gösteren yapılar tespit edilerek, konut sakinleri ile yarı yapılandırılmış görüşmeler yapılmıştır. Görüşmeler sonucunda konut sakinlerinin yaşadıkları konutlardan taşınma talepleri, gündelik yaşamlarının turizmle kurduğu ilişkileri, turizme ve turizmle değişen fiziksel ortama adaptasyonları soylulaştırmanın yerel dinamikleri çerçevesinde değerlendirilmiştir.

Elde edilen değerlendirmelerle çoğunlukla kent ölçeğinde soylulaştırma süreçlerinin incelendiği çalışmaların aksine kırsal sayılabilecek bölgelerin belirli gelişim parametreleriyle karşılaş̧tıktan sonra soylulaşma süreçlerine nasıl dahil oldukları veya olmadıkları, bu süreçte kırsaldaki ye- 
rel parametrelerin nasıl etki mekanizması oluşturduğuna dair tartışma ortamı oluşturulmuştur. Çalışma, soylulaştırmanın yerel bağlamsallık ilişkisini göz önüne serdiği için aslında konunun ne kadar genelleştirilemez ve yerel değerlerin de ne kadar yadsınamaz olduğu durumuna dikkat çekmekle beraber, benzer turizm süreçlerinden geçen kent parçaları için soylulaştırmayı engelleyebilecek parametrelere de ulaşılmasını sağlamaktadir.

\section{Kavramsal Çerçeve}

Soylulaştırma çok yönlü bir kentsel yeniden yapılanmanın bir parçası olduğu kadar aynı zamanda onun bir sonucu olarak da ortaya çıkmaktadır (Şen, 2005, s.129). İçerisinde kentsel dönüşümü, kentsel canlandırmayı, kentsel yenilenmeyi, kentsel yeniden oluşumu barındıran bir süreçtir. Kavramın ilk kullanımı Glass (2010, s.27) tarafından yapılmış ve sosyal adalet ve sınıf vurgusuna dikkat çekilmiştir. Yapılan diğer birçok tanım arasında, arazilerin kârlılık potansiyelini tanımlayan kira açığı (rent gap) gibi üretim tarafına odaklanan (Smith, 2015, s.40) veya mesleklerin ve aile statülerinin değişmesi ile ortaya çıkan şehir içi talepler gibi yönlere odaklanan (Ley, 1996, s.56) ve bu açıklamaların hepsinin soylulaştırma araştırması için yararı ve önemi olduğunu kabul eden tamamlayıcı tanımlar da mevcuttur. Ayn zamanda yabanc ve yerli kaynaklarda, mevcut sinifların hareketliliği ve yeni bir sınıfın ortaya çıkması ile sınıfsal bir "dışlama" etkisi yaratmasından dolayı, kavram çoğu zaman benimsenmemiş ve yerine yeni karşılıklar aranmaya gidilmiştir. Glass tarafından ortaya atıldıktan sonra konu ile ilgili akademik çalışmaların da sayısı artmış ve farklı araştırmacılar tarafından farklı yaklaşımlar ve teorik açıklamalar ortaya atılmiştır.

Kavramın tanımı üretimle özdeşleştirilen yani arz temelli ve tüketimle özdeşleştirilen talep temelli olarak ikiye ayrılmıştır. Tüketim temelli bakış açısı ile Zukin (1987, s.141), soylulaştırma kavramının tanımını tüm sosyal ve mekânsal tanımlarının yanında bireysel tercihler ve demografik yapıdan ziyade üretim ve tüketimin bölümleri altında sınıflandırarak yapmıştır ve belirgin bir şekilde kültürel tüketimle ilişkilendirmiştir. Bu ilişki için kent merkezinde ekonomik gelişmenin üretime nazaran, tüketime daha fazla bağlı olduğundan, soylulaştırmanın daha geniş bir ifade yelpazesini kapsadığını ve kentsel gelişimin anlaşılmasında konunun daha da önem 


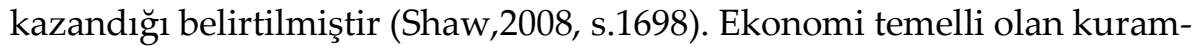
larda ise soylulaştırma sermayenin rant aracı olarak ve emlak değerlerinde oluşan dalgalanma ile açıklanırken (Smith, 2015, s. 40); diğer tarafta kültür temelli olan kuramlarda tam tersine yaratıcı, üst ve orta sınıfın değişen sosyal ve beğeni tercihleri ile açılanmaktadır (Ley, 1994, s.54).

1980'ler, soylulaştırma süreçlerinin farklı teoriler ile ilişkilendirerek açıklamak üzere aşamalı modellerin geliştirildiği bir dönem olmuştur. Bu modellerin temellerinden birisi Clay'in (1979) dört aşamalı modelidir. Clay, dört basamaktan oluşturduğu modelinde, soylulaştırmanın gerçekleşme sürecinin merkezine aktörleri oturtmuştur ve modelin ilk basamağını bölgeye soylulaştırmaya risk oluşturabilecek öncü bir grubun yerleşmesi olarak tanımlamıştır. Öncü grubun bölgede fiziksel dönüşüme başlayarak bir özendirme kaygısına girişmesi, devamında emlak sektörü ve medya sektörünün bölgeye ilgisinin artması ile modelin son aşaması olan konut fiyatlarının giderek artması gibi bir sonuçtan söz edilmiştir. Clay, yaşam alanlarında gerçekleşen fiyat artışıla da bölgeye üst gelir grubunun gelmesinden ve buna bağlı olarak sınıf ayrılıklarıyla gerilim noktalarının oluşmasından bahsetmiş̧ir. Bahsi geçen bu tanımın temelde tüm tanımları ile kesiştiği noktalar olmasının yanında günümüzde "soylulaştırma" olarak görülen kentsel dönüşüm müdahalelerinde de yaşandı̆̆ı gözlenebilmektedir (Aktaran Lees, 2003, s.2491).

20. yüzyılın ikinci yarısından itibaren ise kent merkezinde ortaya çıkan çöküntü alanlarında kullanıcı/sınıf değişimlerini açıklamak için kullanılan soylulaştırma,1990'larda küresel ölçekte yaygınlaşıp (Smith, 2006, s.16) şehirciliğin küresel stratejisi halini almış ve yeni kentleşme dinamikleri arasında kabul gören bir kentsel süreç olmuştur. Çalışma kentsel strateji haline gelen soylulaştırma kavramını, alan çalışmasını da referans alarak, "turizm" bağlamında turizm-soylulaştırma ilişkisi üzerinden ele almıştır. Bugüne kadar klasik soylulaştırma ile ilgili yapılan araştırmalara bakıldığında mekânsal dönüşümlere, alandaki sınıf farklılıklarına, yerinden edilme gibi durumlara odaklanıldığı görülürken, turizm ile ortaya çıkan soylulaştırma bundan farklı olarak sürecin sadece konut odaklı olmadığını, yapı türünün çeşitlendiğini, bu bağlamda ticari birimlerde de soylulaştırma sürecinin izlerinin sürülebileceğini belirten bir kavram olarak karşımıza çıkmıştır. Literatürde turizm soylulaştırmasının ilk tanımını yapan Gotham (2005, s.1101), turizm soylulaştırmasını orta sınıf bir mahallenin, kurumsal eğlence ve turizm mekânlarının çoğalmasıyla nispeten 
zengin ve ayrıcalıklı bir çevreye dönüştürülmesi olarak tanımlamıştır. Turizm soylulaștırması, mahallelerin varlıklı tüketicilerin, sakinlerin ve ziyaretçilerin ihtiyaçlarına göre dönüştürüldüğü sosyo-mekânsal değişim süreci olarak da tanımlanabilir. Judd (1999, s.36) turizm ve soylulaştırma kavramlarını açıklarken birbirinden beslenmekte olduğunu ve zamanmekan anlamında örtüştüklerinden bahsetmiştir. Bazı durumlarda soylulaştırılmış alanların çoğalması, turistik yerler haline gelirken, diğer durumlarda turizme yönelik kentsel tanıtım stratejileri, daha yüksek gelirli yeni sakinleri kendine çeken ve bu nedenle soylulaştırma süreçlerini teşvik eden yeni bir yapılı çevre üretmektedir. Hangi sürecin diğerini teşvik ettiğine bakılmaksızın, sonuç her ikisinin de aynı kentsel ortamda bir arada olma eğiliminde olduğu ve bunun da turizm soylulaştırması olarak adlandırılan duruma yol açtı̆̆ı; mekânın, gittikleri yerde benzer kentsel ortamlar talep eden ve üreten kozmopolit bir orta sınıf için üretildiği ve tüketildiği bir süreç olarak tanımlanmasıdır Judd (1999, s.36). Çalışma kurgusunu Judd'un bahsettiği mekânsal dönüşüm üzerine oturtmuş ve mekânsal dönüşümün ortaya çıkardığı sınıf farklılıklarının gelişimini turizme odaklamış kırsal bir bölgede nelere sebep olduğunu irdelemiştir.

Turizm soylulaştırması, hem ampirik olarak bir cazibe merkezi oluşturup, ortaya çıkardığı mekânsal tutarsızlıkları inceleme anlamında, hem de teorik olarak, karar vericilerin turizmi kentsel, kültürel ve ekonomik yapılanma şeklinde bir araç olarak kullanma biçimi anlamında, önemli bir araştırma ortamı sunmaktadır. Bu anlamda Gotham (2018, s.3) turistik mekanları ve turistik hareketleri, karşıt grupların kültürel sembollerinin üretimini, temsilini ve tüketimini kontrol etmek için savaştığı bir çekişme alanı olarak tanımlamaktadır. Bu çok yönlü kavramsallaştırmada turizm hem baskıcı hem de olumsuz niteliklerin yanı sıra temsil politikasını ve kentsel anlam yaratma politikasını yansıtan dirençli ve dönüştürücü nitelikler içermektedir (Gotham, 2018, s.4). Burada vurgulanmak istenen, ticari soylulaştırma hatta literatürdeki tanımı ile ticarileşmeye/metalaştırmaya (commodification) atıfta bulunmak olup turizmin soylulaştırma ile toplumsal etkisinin yanı sıra mekanların dönüşümü üzerinde de ciddi etkisi olduğuna işaret etmektir. Yerleşim alanlarının ticari olarak geliştirilmesi ve bunun sonucunda üst gelir grubu için eğlence/boş zaman değerlendirme ve tüketim alanlarına dönüştürülmesi toplumsal olarak yerlileri yerinden etme itici gücüne sahip olduğu gibi yerel halkın kullandığı gündelik ticaretin de mekânsal olarak dönüşümüne sebep olmaktadır. 
Bu durum yerli halk ve bölgeyi geçici olarak kullanan turistler arasındaki etkileşimi sorgulamayı da gerektirmektedir. Klasik soylulaştırma yeni bir orta sınıfı ortaya çıkarmışsa, turizm soylulaştırması da geçici bir sınıfı temsil etmektedir. Dönemsel olarak değişen bir nüfus oluşturan bir dizi tüketici profili yaratmaktadır. Gelen hareketli sınıfın bir yaşam tarzı modeline sahip olduğu ve bu kapsamda geldiği bölgenin yerel sakinleri üzerinde ezici bir güç ortaya çıarabileceği ihtimalinden bahsetmiştir. (Gant, 2018, s.32). Ziyaretçiler için bölge bir eğlence ya da kültür odaklı boş zaman değerlendirme alanıdır ve kimi zaman yerlilerin gündelik yaşamlarına olumlu/olumsuz etkileri olması kaçınılmazdır. Bu durum yerli halkın aidiyet duygusunu etkilerken, mülksüzleştirme hissini beslemekte ve alanın "diğerleri" tarafından ele geçirilmesine sebep olmaktadır. Öte yandan bu durumun aksine turistin yeni bir kentte yerlinin günlük yaşam izlerini aradığı, kendini bir gezginken oralıymış gibi hissetmek istediği bir duygu durumu da söz konusudur (Gant,2015, s.13). Bu durum yerli sakinlerle yeni sınıfın ilişkilerinin sorgulanması ve talep/arz odaklı soylulaştırma sürecinin fiziksel ve toplumsal etkisinin önemini gözler önüne sermektedir. Ne var ki ortaya çıkan bu iki çelişkili durum turizm soylulaştırmasının hem sınırlandırıcısı hem de tetikleyicisi olarak adlandırılabilir.

Soylulaştırmanın turizm ve geleneksel tanımlarının benzer-ortak noktaları da vardır. Her iki sürecin de çöküntüleşmeye başlayan tarihi bölgelerin yenilenmesine olan katkısı yadsınamaz. Ancak duruma fiziksel yenileme kapsamında indirgeyici bir bakış açısıyla yaklaşmak sürecin toplumsal boyutunu görmezden gelmek anlamına gelmektedir. Buna destek olan durum ise yerel yönetimlerin, karar vericilerin, özel sektörün turizmi ve gözde tarihi bölgelerin cazibesini bir araç olarak kullanarak yenileme politikalarını oluştururken tüm soylulaştırma türlerinde devlet desteğinin yerel bölgesel bağlama ne kadar dikkat ettiği sorusunu gündeme getirir. Bahsi geçen bu durum alan çalışmasında yerli halk ile yapılan görüşmelerle detaylandırılmıştır.

Turizm soylulaştırmasının akademik yazında belirlenen önemli metropol kentler üzerinde pek çok alan araştırmasıyla incelendiği görülmüştür (Kesar, Dezeljin ve Bienenfeld ,2015; Liong ve Bao, 2015; Perez, 2019). Çalışmaların turizm soylulaştırmasını kentlerin mevcut durum analizlerini ortaya koyduğu ve genellikle soylulaştırmanın toplumsal olarak olumsuz sonuçlarına odaklanan bir hedefle ortaya çıktığı görülmüştür. Bu kap- 
samda çalışmanın diğer turizm soylulaştırması çalışmalarından farklı olarak soylulaştırmanın sınırlarının/tetikleyicilerinin ve sonuçlarının yerel parametrelere bağlı olabileceğini ve her bölgede farklı bir sosyo-kültürel soylulaşma olabileceğini savunması ile literatürde ayrı bir yeri olacağı düşünülmüştür.

\section{Tarihi Gelişimiyle Uçhisar Beldesi}

Uçhisar, Nevşehir'in merkez ilçesine bağlı ve şehir merkezine 7 km uzaklıkta bulunan bir beldedir. 1985 yılında Birleşmiş Milletler Eğitim-Kültür ve Bilim Teşkilatı (UNESCO) tarafından dünyanın Olağanüstü Güzellikte Doğal ve Kültürel Mirası listesine katılmış ve 1986 'da kasabanın çeperinde bulunan ve mevcut konumuyla pek çok turistin doğa yürüyüşlerine ev sahipliği yapan Göreme Doğal ve Tarihi Milli Parkı da koruma altına alınmıştır (Uçhisar Belediyesi, 2020) (Şekil 1).

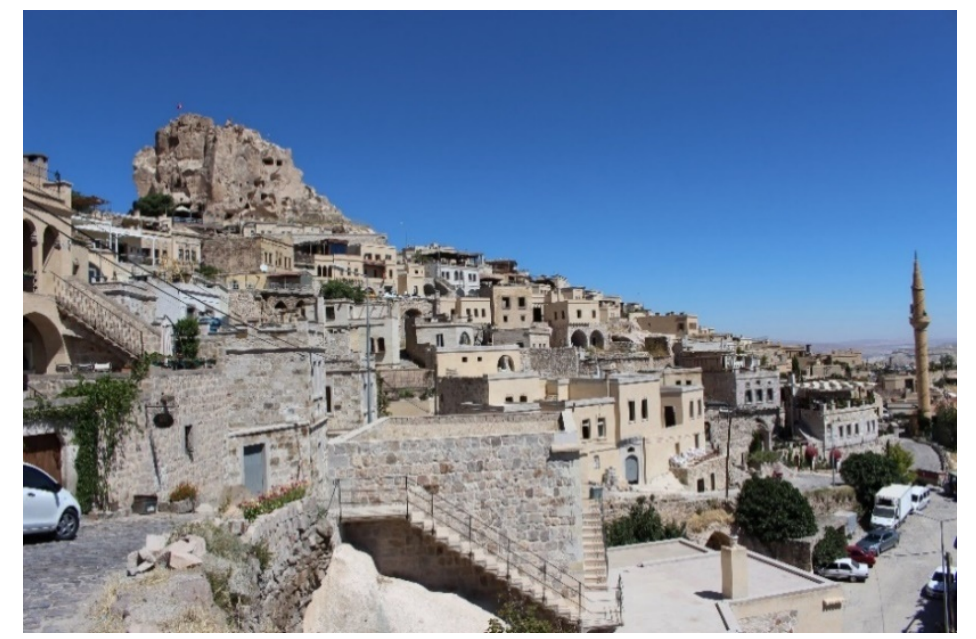

Şekil 1. Uçhisar Kalesi ve etrafı (Görsel yazarın fotoğraf arşivindendir.)

Nevşehir- Göreme yolu üzerinde bulunan Uçhisar, aynı zamanda Kapadokya bölgesinin savunma amaçlı tepe yerleşkelerinden biridir. Sınırları içine, bir dönem savunma amacına hizmet etmiş ve 1960'lara kadar içinde yaşanmış, günümüzde de turizm amacıyla çokça ilgi gören Uçhisar Kalesi'ni barındırmaktadır. Roma döneminden beri içerisinde kayadan oyma çok sayıda oda, sığınak, depo, sarnıç gibi birimleri bulunmuştur. Kale ve eteklerinde bulunan yaşama birimlerinin yapılışının çok eski dö- 
nemlere dayandığı ve günümüzde de ayakta kalan pek çok yapının restore edilerek kullanıma açıldığı görülmektedir. Çalışmada bahsi geçen bu çevre üzerine yoğunlaşılmış ve beldenin nirengi noktası olan Uçhisar Kalesi ve etrafı üzerine incelemeler yapılmıştır.

1960'lı yıllarda Uçhisar Kalesinin çevresi kayaların yıkılma tehlikesinden dolayı "afet bölgesi" ilan edilmiş ve kalenin eteklerinde yaşayanlar kasabanın güneyine doğru yeni yerleşim yerini oluşturmaya başlamıştır. Özbay (2018, s.21), devletin o dönem afet bölgesi olarak belirlenen yerlerde yaşayanlara herhangi bir ücret karşılığı olmadan, imarlı arsa verdiğini ve bunun pek çok tarihi dokuya sahip köyde olduğu gibi, Uçhisar Kalesi eteklerindeki tarihi evlerin de boşalmasına neden olduğunu belirtmiştir (Şekil 2). Bu nedenle kale etrafı harabe haline gelmekle kalmayıp, yeni yerleşim yerine yerleşenlerin devletin tanımış olduğu imkanların yetersizliği sonucu, oturdukları eski evlerinin malzemelerini alarak yeni konutlarının inşasında kullandığı, bunun da kale etrafının bakımsızlığını daha da arttırdığı belirtilmiştir. Bölgenin bu çöküntüleşmeye yaklaşmış dokusunu harabe olmaktan çıkararak, tekrar eski tarihi dokusuna ulaşmasina neden olan durum ise 2000'li yıllara yaklaşırken bölgeye gelen bireysel müdahalelerin gerçekleşmesi olmuştur. Yatırımcılar harabe olan bu evleri satın alarak restorasyon çalışmalarına başlamış ve bölgenin turizmle tanışma hikayesi de bu yıllarda ortaya çıkmıştır. Restore edilen yapılar yavaş yavaş otel, restoran, dükkân gibi konut dışı fonksiyonlarla kullanıma açılmıştır.

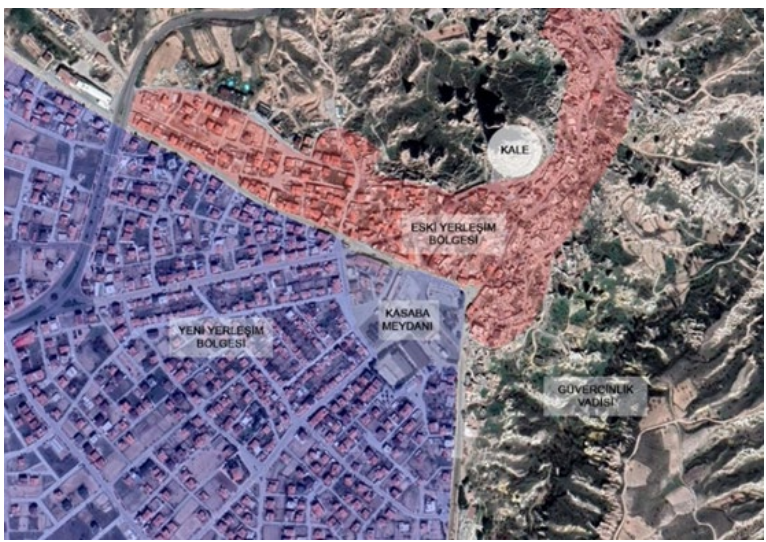

Şekil 2. Uçhisar eski ve yeni yerleşim bölgesi (2020 yılı Google Earth görüntüsü altlık olarak kullanılmıştır.) 
Bugün içerisinde 61 otel ve pansiyon 86 diğer ticari birim (yeme-içme birimleri, turizme hizmet eden dükkanlar) mevcut olan Uçhisar beldesi gündelik yaşamı turizmle iç içe geçmiş, yerli halkın çoğunlukla turizmle geçimini sağladığı bir bölge haline gelmiştir (Uçhisar Belediyesi, 2020). Bu durum beldenin hem sosyal yapısının turizmle ilişkisini artırmış, hem de turizmle beraber fiziksel çevrenin değişimini sağlamıştır.

\section{Uçhisar'da Turizm -Soylulaşma İlişkisinde Yerel Dinamikler}

Uçhisar'ın araştırma alanı olarak seçilmesinde pek çok etken mevcuttur. Bunlardan en önemlisi son dönemde metropoliten kentlerde ortaya çıkan ve hatta yenileme stratejisi olarak kullanılan soylulaştırma sürecinin kırsal olarak değerlendirilebilecek bir bölgede yerel dinamiklerle birlikte hangi süreçlerden geçtiğini gözlemlenebileceği bir bölge olmasıdır. Bölge için nitelendirilen "kırsal" tanımlaması, kent merkezinden uzak olmasının yanı sıra halen yerli halkın gündelik hayatında yerel dinamiklerin korunması, tarihi koruma alanı olduğu için kentsel anlamda büyük ölçekli müdahalelerin yapılmaması ve beldenin fiziki ve sosyal dokusunun korunmaya çal1şılmasını kapsamaktadır. Bölgenin seçilmesinde diğer bir etken ise Roma döneminden günümüze pek çok yaşam modelini içinde barındırması ve çok kültürlü bir bölge olmasıdır. Hem Uçhisar Kalesi'nde hem de kale etrafında hatırı sayılır tarihi doku olması, halen günümüzde restorasyon çalışmalarının devam etmesi, hali hazırda fiziksel gelişimine/yenilenmesine özel ve kamu müdahalesi ile devam etme durumu bölgede soylulaştırmanın görülme olasılığının araştırılmasına destek veren verilerdir.

Öte yandan sahadan edinilen aktarımla bölgede geçim kaynağ 1 tarımken 2000'li yıllarda turizme hizmet eden ticari birimlerin artması ile yerli halk geçimini turizmden sağlamaya başlamıştır. Bu durum hem bölgede birçok yapının bireysel ve yerel yönetim müdahalesi ile turizme dahil edilme bahanesiyle dönüşmesine neden olmuş, hem de yerli halkın "turist sınıfı" ile etkileşimde bulunarak gündelik hayatlarını bu olgu üzerine kurmalarına sebep olmuştur. Aynı zamanda bölgenin konut ağırlıklı bir yerleşim planı varken, turizmle beraber pek çok ticari işlevin yöreye gelmesi ile bölgenin gelir seviyesi yüksek kesime hitap eden bir anlama sahip olmasıyla ortaya çıkan sosyal sorunların gözlenebilirliği de söz konusudur. Bu anlamda turizm soylulaştırmasının fiziki ve sosyal ortamı dönüştürmesi bakımından analiz edilecek birçok veri bulunduğu düşünülerek Uçhisar beldesi analiz edilmiştir (Şekil 3). 

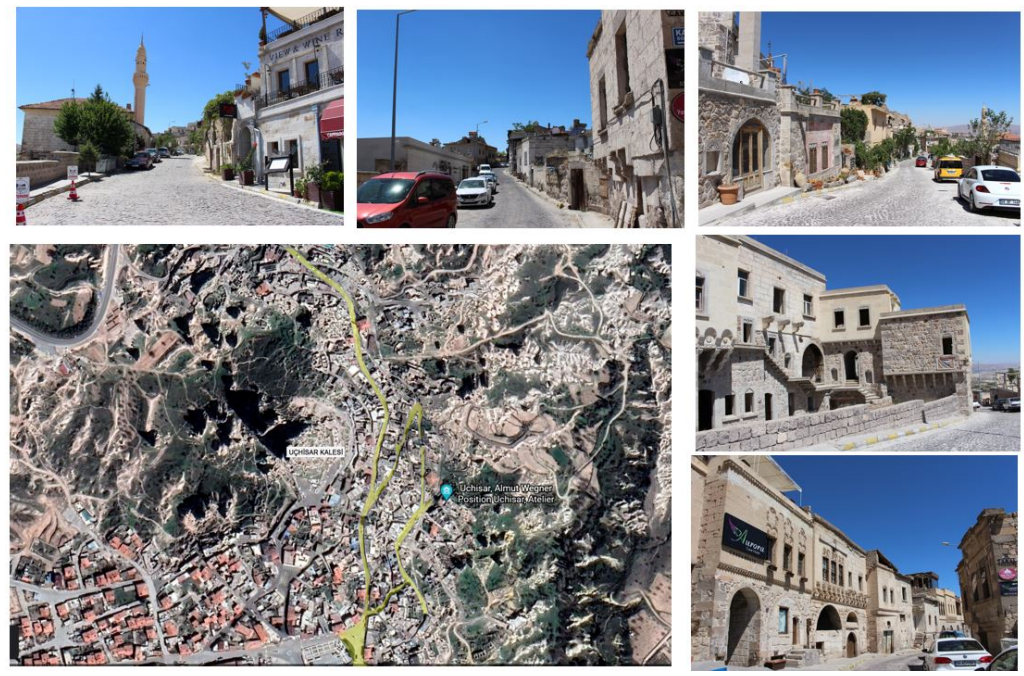

Şekil 3. Alan araştırması için seçilen yol ve etrafındaki otel yerleşimi (Görseller yazarın fotoğraf arşivindendir)

Son olarak bölgenin araştırmaya değer görülmesindeki önemli nedenlerden biri de soylulaştırma yaşanan bölgede ortaya çıan "yer değiştirme" durumudur. Uçhisar'ın kuşbakışı görünümünde, kale etrafı tarihi dokusu sebebiyle eski yerleşim, afet bölgesi sonrası yapılaşmaya açılan yerleşim bölgesi de yeni yerleşim olmak üzere ikiye ayrılmıştır. Bunun yanında kale etrafında gerçekleşen ticari dönüşümün mevcut kullanıcı üzerinde yer değiştirme baskısı yaratıp yaratmadığını araştırabilecek ortam sunması da bölgenin çalışma alanı olarak seçilmesinde etkili bir veridir. Tüm bu veriler ışığında çalışmada yöntem olarak öncelikle fiziksel verileri tespit etmek üzere yerinde gözlem yöntemi kullanılmıştır. Kale etrafında konutların tespiti için alan çalışması otellerin yoğunlukta olduğu bir köy yolu olan Göreme Caddesi'yle sınırlandırılmıştır (Şekil 4). Şekil 4'te gösterilen kale etrafını saran ve çoğunlukla otel girişlerinin olduğu ve birçok otele cephe veren işaretli yol üzerinde halen konut olarak kullanılan otellerin arasında kalmış konutlar tespit edilmiştir (Şekil 5). Saptanan yedi konuttan beşinin içinde en az 30 yıldır bu konutlarda yaşayanlarla görüşmeler yapılmıştır. 


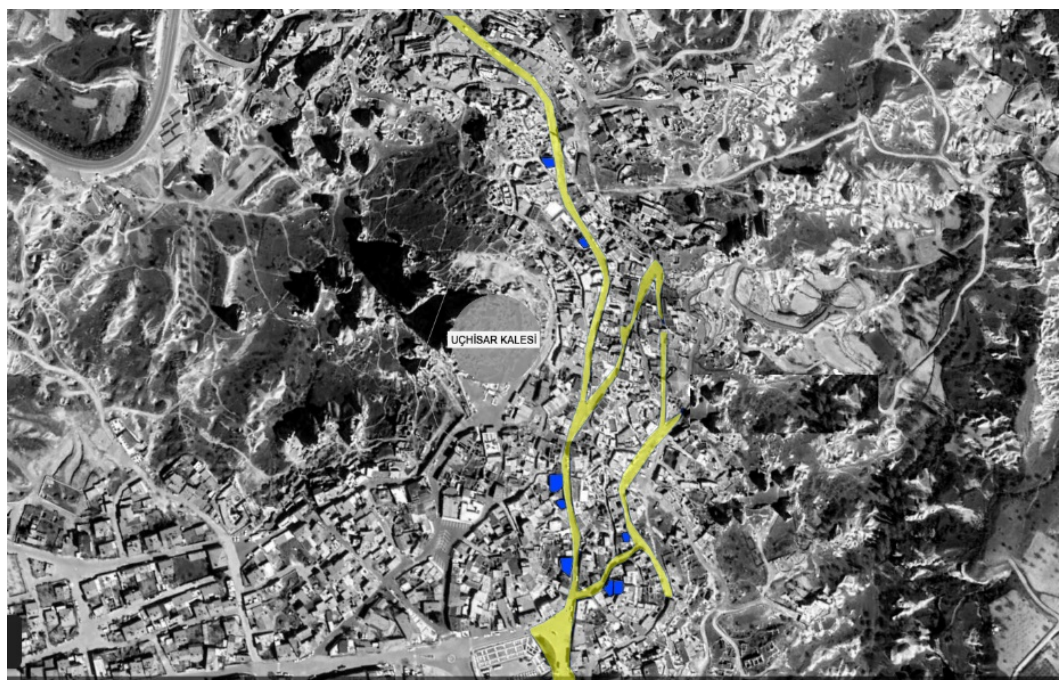

Şekil 4. Seçilen güzergah üzerinde bulunan ve halen konut olarak kullanılan yapılar (2020 yılı Google Earth görüntüsü altlık olarak kullanılmıştır.)

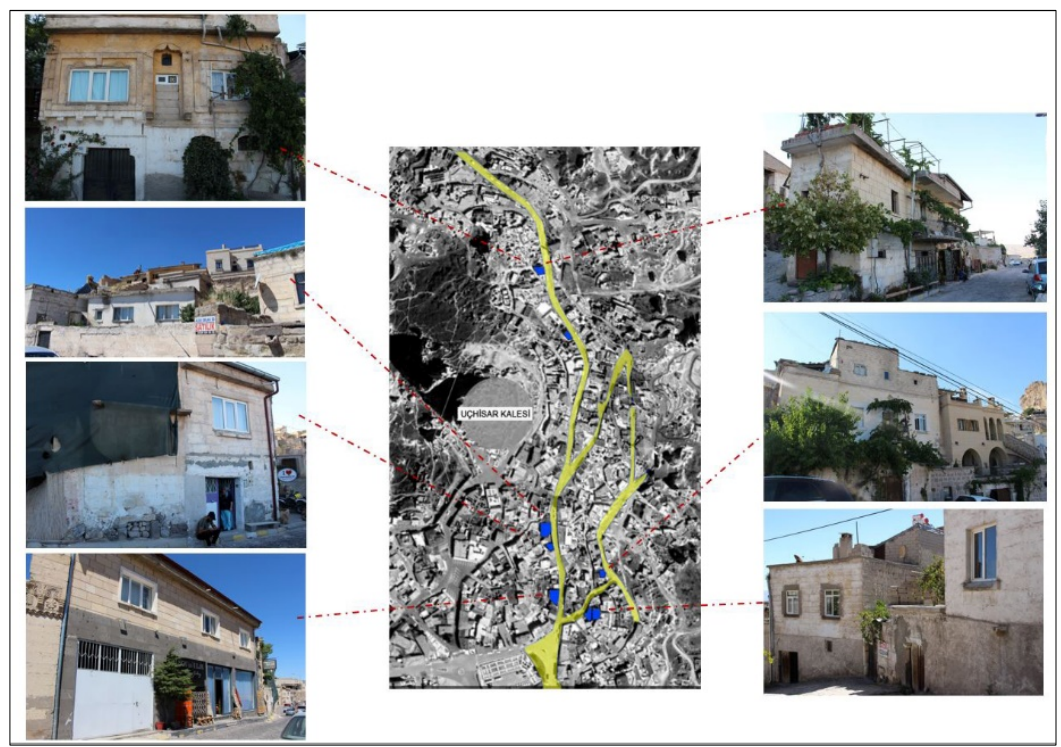

Şekil 5. Seçilen güzergâh üzerinde konut olarak kullanılan yapılar (Görseller yazarın fotoğraf arşivindendir.)

Konutlara Uçhisar'da kaç yıldır yaşadıkları, taşınmayı düşünüp düşünmedikleri, çevresinde daha önce taşınanların hangi sebeple taşındıklarını, turizmle beraber gündelik hayatlarında herhangi bir baskı hissedip hissetmedikleri, bu bölgedeki değişimler hakkındaki fikirleri ve buraya ait 
hissedip hissetmedikleri, yerel yönetimlerin bölgeye müdahaleleri hakkındaki fikirleri sorulmuştur. Tüm bu soruların amacı, bölgenin değişimine uzun yıllar tanıklık etmiş yerli halkın görüşleriyle, bölgenin yerel dinamiklerini tespit ederek bu bölgede soylulaştırma durumunu engelleyen veya tetikleyen, soylulaştırma ile gelen olumlu/olumsuz parametrelerin tespit etmektir.

\section{Bulgular ve Tartışma}

Çalışmada, Uçhisar Kalesi'ni saran ve çeperinde çoğunlukla ticari birimlere cephe veren bir yol, güzergâh olarak seçilmiş ve analizlere çoğunlukla bu yolun etrafında bulunan otellerin ve diğer ticari birimlerin aralarında halen konut olarak kullanılan yapıların tespiti ile başlanmıştır. Yol üzerinde toplam yedi konuttan beşinin içerisinde yaşayan konut sahipleri ve sakinleri ile soruların çoğu zaman konuşma esnasında geliştiği ve bölgenin değişimine olan yaklaşımlarının sorgulandığı yarı yapılandırılmış görüşmeler yapılmıştır. Görüşmeler, hafta içi gündüz 12.00- 17.00 saatleri arasında gerçekleştirilmiş ve mesai saatleri olması sebebiyle o saatlerde izinli olan- herhangi bir işte çalışmayan ve çoğunlukla da ev hanımı olan hane halkı ile görüşmeler gerçekleştirilmiştir.

Görüşmeler ışığında soylulaştırmanın yerel dinamikleri sorgulanırken öncelikle kavramın önceki tanımlarından günümüze kadar ulaşmış bazı parametreler üzerinden hareket edilmiştir. Bunlardan ilki soylulaştırmayla gelen "yer değiştirme" baskısıdır. Kale etrafında otellerin giderek artması ile konut sakinlerine yaşadıkları bölgeden taşınma baskısı hissedip/hissetmedikleri ve taşınıp/taşınmayacakları sorulmuştur. Görüşmelerin değerlendirilmesinden önce, bu durumun sayısal verilerle desteklenmesi amacıyla son 50 yıl içerisinde Uçhisar beldesinin nüfus verileri incelenmiş̧ir. Bölgede nüfus verilerindeki değişimin otel ve ticari birimlerin sayısının artması dönemine denk gelip gelmediğinin analiz edilmesi, soylulaştırma sürecinin başlangıcını anlamak adına çalışmaya önemli katkı sağlaması düşünülmüştür. Ancak yalnızca çalışmanın kapsamı olan kale etrafının nüfus verilerine ulaşılamamıştır. Aynı zamanda kale etrafından taşınanların 1960'l1 yıllarda afet yasasından sonra Uçhisar'ın yeni yerleşim bölgesine taşınması da Uçhisar'ın soylulaştırma kapsamı içindeki nüfus dalgalanmalarının tespitinde sağlıklı veriler sunamamaktadır. Çünkü kale etrafından taşınanların çoğunun o dönem Uçhisar meydanının güneyine doğru yeni bir yerleşim yerine taşındığı söylenmektedir. Bu nedenle 
soylulaştırmada yer değiştirmenin temel kanıt sürecinde nüfus verileri değerlendirmeye alınmamıştır. Bu kapsamda, bir bölgede kamu ya da özel sektörün müdahalesi ile soylulaştırma sürecine giren bir bölgede yer değiştirme yaşanmaması için bölgenin alternatif yerleşim imkanlarına sahip olması önemli bir yerel dinamik olarak görülmüştür. Bunun yanında görüşmelerde mevcut konut sakinleri için turizm itici güç olmaktan ziyade kullanıcıların turizmle entegre bir hayata uyum sağlamaya çalıştıkları, hatta gelirlerinin bir kısmını turizmden sağladıkları için etrafta otellerin artması ve beldenin turistlerce ziyaret ediliyor olmalarından memnun oldukları ortaya çıkmıştır.

Soylulaştırmanın turizmle birlikte araştırıldığı çalışmada Uçhisar'ın yerel dinamiklerinden biri de belde halkına ait sokakların, yolların, peri bacalarının kullanımının son dönemde artan otel ve ticari birimler tarafından alıkoyulmaması, kamusallığın kısıtlanmamasıdır. Uçhisar'da çalışma sürecinde yerinde gözlemler yapılırken üst gelir grubuna hitap eden pek çok otel ve restoranın halen Uçhisar halkının da kullandığı sokaklar üzerinde bulunması, bu birimleri kullanmayan veya otelde konaklamayanların da otel odalarının önünden rahatlıkla geçebildiği sokakların var olması bölgede turist-yerel halk etkileşimini güçlendirmekte, aynı zamanda gerilim oluşturacak sınırları da ortadan kaldırarak kamusallık sağlamaktadır. $\mathrm{Bu}$ anlamda bölgenin soylulaşmanın direnç gösteren/tetikleyen yerel dinamiklerinden biri de "kamusallık" olarak ortaya çıkmıştır.

Bölgede soylulaşma kapsamında yerel dinamiklerin araştırılmasında kamusallığın önemi gibi fiziksel değişimin izleri de önem taşımaktadır. $\mathrm{Bu}$ nedenle yerinde gözlemler yapılarak fonksiyon değişimi olan tadilat/restorasyon süreci içinde olan bölgeler incelenmiştir. Hem görüşmelerden elde edilen bulgularda hem de Uçhisar Belediyesi'nden alınan koruma amaçlı imar planlarının incelenmesi ile kale çevresinin günümüzde halen gelişim/yenileme aşamasında olduğu görülmüştür. Bölgenin her geçen gün kamu ya da özel sektörün müdahalesi ile çöküntü olmaya terkedilmesinin önüne geçilmekte ve giderek değerini arttırmaya yönelik fiziksel değişimler yapılmaktadır. Yenilenen yapıların yöre halkının kullanımından çok, özel mülkiyet ile turizm kullanımına açılmış olması üst- orta sınıfın bölgeye hakimiyet kurması anlamına gelmekte ve kendiliğinden oluşan ancak yerel dinamiklerden etkilenen bir soylulaştırmanın izlerine işaret etmektedir. Burada yeni bir sınıfın oluşmasının yanında bölgenin 
çöküntü halinden kurtulması ve yenilenme sürecinde olması soylulaştırmanın getirdiği olumlu sonuçlardan biri olarak görülmektedir. Bunun yanında hem restorasyon çalışmalarının devam ettiği hem de kale etrafında birçok yapının satılık ilanları ile boş bir şekilde beklediği tespit edilmiştir (Şekil 6).
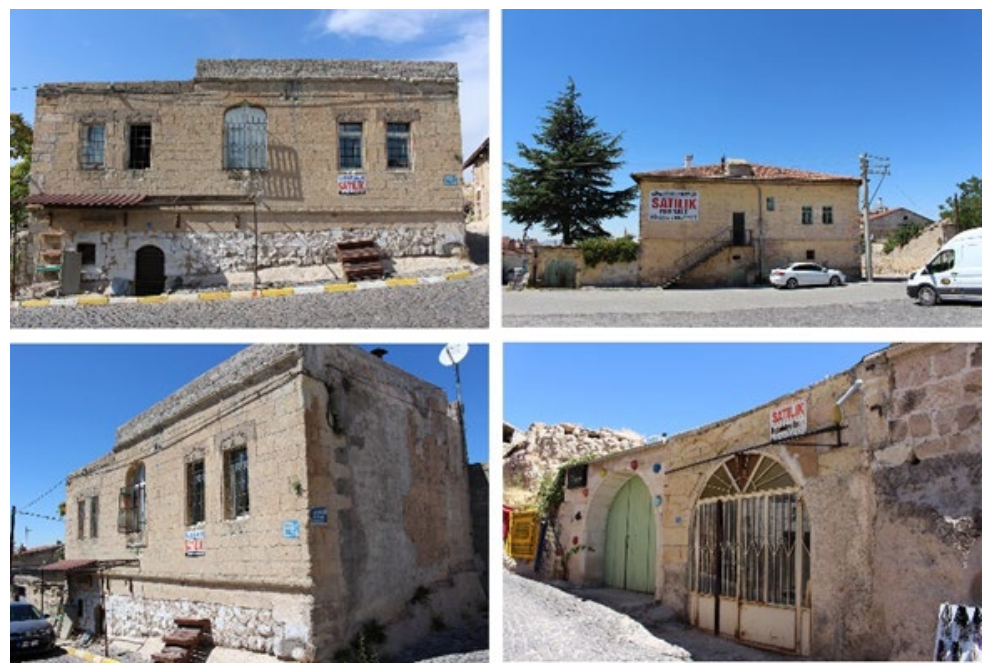

Şekil 6. Uçhisar kale etrafında satılık ilanı olan yapılar (Görseller yazarın fotoğraf arşivindendir.)

Mevcutta yerleşim alanlarının ticari olarak geliştirilmesi ve bunun sonucunda üst gelir grubu için kültür turizminin gerektirdiği boş zaman değerlendirme ve tüketim alanlarına dönüştürülmesi, incelenen kısımda yaşayan yerlileri yerinden etme gücüne sahip olduğu gibi onların kullandığ gündelik ticari birimlerin de turist sınıfının kullanacağı biçimde mekânsal olarak dönüşümüne sebep olmaktadır. Görüşülen konut sakinlerinin bir kısmı bu durumu işaret ederek, çoğunlukla evlerini satmak isteyenlerin satış taleplerinin otele dönüştürmek üzere gelen yatırımclar tarafından olduğunu belirtmiş, içlerinden bir kısmı da bulundukları konutların zemin katını turistik hediyelik eşya satışı yapabilecekleri dükkanlara dönüştürmeyi hedeflediklerini belirtmişlerdi.

"Eşim turizmci, kayınbabam deve ile uğraşıyor. Bizim işimiz turizm zaten. Buranın yerlisiyiz. Turizm gelsin istiyoruz, turistlerden rahatsı değiliz, hatta yerliden iyi turistler. Kimseyi rahatsız etmezler." (Aysel Ö., kişisel iletişim, 25 Ağustos 2020) 
“Bu ev miras evi olduğu için görümcelerim evi satmak için çok fazla para istiyor. Almak isteyen kişi de ucuz verirseniz alırız diyor. Görümcelerim de ucuz vermiyor, en azindan hepimize bir ev etmesini istiyorlar. Onun için şu an satmıyorlar. Zaten müşteri de yok. Evimiz istediğimiz paraya satılsa taşınırı ama ĕ̆er oğullarım burayı alth üstlü dükkân yaparsa taşınmayı düşünmüyoruz." (Semra A., Kişisel iletişim, 26 Ağustos 2020)

Soylulaştırma tanımı gereği, yeni bir sınıfın mevcut sınıfı yerinden etmesi durumunu işaret ettiği için bölgede mevcut konut sakinlerinin evlerinden taşınma/ taşınmama sebepleri de Uçhisar için soylulaştırmanın yerel parametrelerini bulma konusunda önemli veriler sunmaktadır. Bir k1sım görüşmeci evlerini satılığa çıkardığını belirtmiş, ancak satın almaya niyetli olanların satış bedelini pahalı bulmaları sebebiyle satın alamadıklarını iletmişlerdir. Bu durum bir dönem çöküntü haline gelen bölgede münferit adımlarla oldukça düşük fiyatlar karşlığı satın alınan konutların, günümüzde bölgenin değerinin turizm aracılığıyla artmasıyla mülk sahiplerinin mülkiyet değerlerini arttırdığı ve satın alınabilirliğin (affordibility) zorlaşması durumunu ortaya çkarmıştır. Buna ek olarak sahada yapılan görüşmelerde kira bedellerinin de arttırıldığı, kaleye yakın bölgelerde pek çok dükkânın dolar üzerinden kira bedelini ödedikleri bilgisine ulaşılmıştır.

“Oteller buraya gelip soruyorlar, ama onlara da pahal geliyor biraz. Yaklaşmıyorlar. Bizim ev biraz büyük. Hep kayadan oyma altı. Ucuza gitsin istemiyoruz. Çocuklara ev parası çıssın istiyoruz" (Fatma Ç., kişisel iletişim, 25 Ağustos 2020)

"Müssteri gelmiyor, pahalı buluyor, satmak istiyoruz ama. Oteller geliyor genellikle soruyor. Hala kaya damlarımız var bizim aşă̆ıda, otel odası olabilir buralar." (Aysel Ö., kişisel iletişim, 25 Ağustos 2020)

Sakinlerin çoğu yukarıda bahsedilen sebeplerden farklı olan taşınma sebeplerinden de bahsetmişlerdir. Bunların en başında konutların neredeyse 30 yıllık bir geçmişi olmasından dolayı tadilat gerektirmesi ve tadilat masraflarını konut sahiplerinin karşılayamamalarıdır. Öte yandan bu konutlar sit alanı sınırları içindedir ve yapılan her bakım müdahalesi için izin ve denetim gerekmektedir. Tüm bunlar evlerin bakımının yapılama- 
masına, eskimesine sebep olmaktadır. Bu etkenler de gelir seviyesi yüksek, konutları yenilemek amacıyla yatırım yapabilme gücüne sahip yatırımcıları bölgeye davet eden sonuçlar doğurmaktadır. Diğer bir taşınma sebebi olarak tesisat sorunu dile getirilmiştir. Pek çok evin zemin katı ve bodrum katı halen kayadan oyma birimleri içermekte ve bölgeye hem bu sebeple hem de koruma bölgesi olması nedeniyle ssınma, su gibi tesisat çalışmaları yapılamamaktadır.

"Bakım yaptırmak için bayağı bir maliyet gerekiyor. Bizim de ona gücümüz yetmeyeceği için yaptıramıyoruz. Zaten evlerin otel olması için de çok talep var. Benim çalışı̆̆ı̆m otel de (evinin karşısı) eskiden bir evdi. 2-3 tane evdi. Birleştirdiler büyük otel yaptılar. 1 senedir inşaattaydı. 2 ay oldu açılal. Eskiden burada oturuyorlardı. Komşularımızdı. Sonra burayı sattılar gittiler. Yeni ev yaptırdılar." (Songül G., kişisel iletişim, 26 Ağustos 2020)

"Yanımız bakımsızlıktan yıkıldı iyice harabe olmuştu, komşumun eviydi orası, yıkılınca Nevşehir'e taşınmak zorunda kaldılar. Yaptıramadılar. Bu evler tescilli. Burası satıldı alan kişi eskiye göre yenileyecek." (Semra A., kişisel iletişim, 26 Ağustos 2020)

Yukarıda bahsedilen sebepler soylulaştırma sürecinin hem başlangıcı hem de önlenebilecek baskın bir parametresi olarak ortaya çımıştır. Çünkü bakım/onarım masraflarının tarihi bir bölgede belli bir sektörel desteği olmaksızın yapılabilmesinin zorlaşması kullanıcıların yaşam alanlarının bakımsızlıktan yaşanamayacak hale gelmesine, bölgeyi terk etmeye zemin hazırlamasına, tarihi değer bilinciyle bakımsız olsa bile mülkiyet değerinin yüksek tutarak satılmasına neden olmaktadır. Burada soylulaştırma literatüründe sıklıkla gözlenen bir üst sınıfın görünür bir yerinden etme zorlaması yoktur, ancak dolaylı yoldan yapıların bakımına destek olunmayarak boşaltılmasına, terk edilmesine yönelik bir girişim olduğu görülmektedir.

Konut sakinlerinin hepsi evlerini bir şekilde satışa sunmak istediklerini ve buradan aldıkları gelirle kendilerine görece daha "yeni ve bakımlı" birkaç ev satın almak istediklerinden belirtmişlerdir. Çoğunlukla satın alma taleplerinin de otele dönüştürmek isteyen yatırımcılar tarafından olduğu ortaya çıkmıştır. Bu sebeple aslında sakinlerin üzerinde turist sınıfının yaşam modeli sebebiyle bir baskı değil, otel işletmecilerinin alanlarını genişletme ya da sermaye oluşturma talebinden dolayı, dolaylı yoldan bir baskı olduğu ortaya çıkmıştır. 
“Evet satabilirsek düşünüyoruz. Hep çevremizdekiler satıldı, bir biz kaldık ortada. Baskı hissetmiyoruz ama eşim vefat etti çocuklar için bu evi satıp bölüşülmesini istiyoruz. Ben de bir ev alayım, çocuklar da birer ev alsin herkes alsin otursun istiyoruz." (Serap T., kişisel iletişim, 26 Ağustos 2020)

Konutlardan taşınma talepleri sorgulanırken bir taraftan da tüm görüşmecilerin kendilerini bölgeye ait hissedip hissetmedikleri sorgulanmıştır. Turizmin bölgeyi değiştirmesi ile artık eski yaşadıkları çehre değişiyor olsa da yıllardır Uçhisar'da yaşadıklarını ve taşınmak istemelerinin bölgenin değişimiyle ilgili olmadığını belirtmişlerdir. Bu durum, bölgede fiziksel değişim ve farklı sosyal sınıfların gelmesine uyum sağlayabildiklerini ve gündelik yaşamlarını buna göre dönüştürdükleri sonucuna ulaştırmıştır.

"Evet tabii ki. Taşınsak bile hala geçmişim gençliğim burada hep. Her taşında topră̆ında bir anım var o yüzden ait hissediyorum." (Serap T., kişisel iletişim, 26 Ağustos 2020)

"Ait hissediyoruz. Ama eskiden daha güvenliydi. Eskiden kapmmn önüne otururlarmış, o zaman turist de yokmuş zaten. Eski evler satılmaya başlayınca değişti buralar." (Songül G., kişisel iletişim, 26 Ağustos 2020)

"Nerede karnm doyuyorsa orahsin. Ait hissediyoruz ama. Turizm hayattmızı etkiliyor ama biz burada doğup büyüdüğümüz için vazgeçemiyoruz. Eski günleri arıyoruz tabi." (Fatma Ç., kişisel iletişim, 25 Ağustos 2020)

Ancak konut sakinlerinin her ne kadar beldeye karşı aidiyet hissetseler de çoğunlukla satın alınan konutlara yabancıların yerleşmesinden dolayı korktuklarını dile getirmeleri dikkat çekmiştir. Öte yandan bulundukları konutun değerini bilen, beldeye buraya yıllarını vermiş konut sakinlerinin sahip çıkması gerektiğini belirten konut sakini de bölgenin ve komşularının turizmden nasıl etkilendiğini ve gidenlerin mevcut kullanıcı üzerindeki etkisini şu şekilde anlatmıştır;

"Şimdi diyorlar ki yabancılar bu tarafi sardı diyorlar. Herkes bizim gibi evini yaptırip burada otursaydr içinde yabancilara vermezdik. Kendi elimizle yabancllara veriyoruz. Gelirken gördüğ̈nüz o vadideki evlerin hepsi hep satıldı. $O$ zamanlarm satılmasından hariç şimdi tekrar ikişer üçer el değiştiriyor. Şimdi de turizm için satın alınıyor. Arkadaki yapıları hep satın aldılar. Eskiydi kimse yaşamıyordu orada ama. 90'l yillarda oturuyordu ama oralarda. Gün be gün 
kimse kalmadı. Şimdi bize de söylüyorlar. Bir siz kaldını diyorlar. Yabancı oldu hep siz de satm gidin diyorlar. Yalnı olduğumuzu görünce komşu vs. yok burada biz ordayiz siz de gelin diyorlar. Ben de diyorum ki herkes burası değerli diye ufacık bir yeri almaya çalışıor da ben niye evimi satayım değerli olduktan sonra." (Semra A., kişisel iletişim, 26 Ağustos 2020)

"Burayi yabancilar aliyor hep. Yabancilar alinca sanki hep onlara kalacakmış gibi bir his oluyor. Hep yabancllar gelecek bizi buradan atacaklar gibi hissettiğimiz oluyor. Çevredekilerin de hep böyle bir düşüncesi var, yabancılar alacak bizi buradan gönderecekler gibi geliyor bazen. Türklerden değil ama Fransa, Almanya gibi dış ülkelerden gelen zenginler için endişeleniyoruz." (Aysel Ö., Kişisel iletişim, 25 Ağustos 2020)

Soylulaştırma yeni bir sınıfın ortaya çıkmasını işaret ederken Uçhisar için bu durum geçici bir sınıf olan turistleri göstermektedir. Bölgeye gelen yeni ve kalıcı olmayan kullanıcının mevcut kullanıcı üzerinde gelir farklılıkları ve mevcut fiziksel şartlar üzerindeki arz-talep uyumu konusunda baskı yaratması gibi durumlar sebebiyle toplumsal gerilim noktalarının ortaya çıkması, soylulaştırmanın göstergelerinden biri olarak görünmektedir. Ancak Uçhisar örneğinde yapılan görüşmeler sonucu bu durumun farklılaştı̆̆ı, hatta görüşme esnasında "turist buranın her şeyi, onlar hep olsun, turizm de geçim kaynağımız” şeklinde açıklamalar yapıldığı görülmüştür. Bu anlamda, yöre halkının turizmle bir gelir kapısı ve istihdam elde etme durumu mevcut kullanıcının bölgeyi terk etmesini engellemesi açısından bir soylulaştırma yerel dinamiği olarak görülebilmektedir.

Öte yandan, fiziksel çevrenin değişiminin sosyal sorunlara neden olması sebebiyle Uçhisar'ı neredeyse 30 yıldır tanıyıp değişimini izleyebildikleri için konut sakinlerine, çevrede harabe olarak kalan konutların restorasyon çalışmaları ve çevre yapıların yenilenmesi hakkında görüşleri sorulmuştur. Görüşmeciler bölgenin temiz ve yeni olmasından memnun olduklarını dile getirseler de bazı görüşmeciler buna ek olarak başka sorunlardan da bahsetmişlerdir.

“Günlük hayatımızı etkilemiyor ama sonradan yapılan yerler biraz manzaramızı etkiliyor. Ona biraz üzülïyorum ben. Eski konumunda kalmıyor hiç. Teras yapıyorlar terası camla çeviriyorlar, brandayla çeviriyorlar, yani özelliği kayboldu köyümüzün. Madem öyle camekana çeviriyorsunuz o zaman akvaryumda yaşıyor gibi bir halin var senin. 
...Belediye bunlara ses çıkarmıyor, nasıl çıkarmıyor anlamıyorum. Zengine göz yumuluyor. Diğeri de diyor ki madem ona ses çıkarmadın bana da ses çıkarma ben de yıkıp yapayım. Böyle sorunlar var burada." (Semra A., kişisel iletişim, 26 Ağustos 2020)

"Bazı kurulda olan evler var. Oralara çok müdahale edemiyorlar. Ama kurul kapsaminda olmayan yapılara biraz daha dokunabiliyorlar. Ama yine de devlet eliyle turizm bakanlığından geliyorlar, proje sunuluyor. Onayına göre yapılıyor." (Songül G., kişisel iletişim, 26 Ağustos 2020)

Sorulan tüm sorular aslında önem verilmesi gereken diğer bir bağlam olan sosyal sürdürülebilirliği de işaret etmektedir. Yöre halkının gündelik yaşam pratikleri, eylemlilikleri ve zaman mekân haritaları göz önüne alınarak bir değerlendirme yapılması gerekmektedir. Mekânın, yöre halkının sürdürdüğü mekânsal pratikler olmadan korunması ve "soylulaşması" mümkün değildir. Bu anlamda konut sakinlerine turizmle başlayan fiziksel ve sosyal değişimle gündelik hayatlarının nasıl farklılaştığı sorulmuştur. Önceki kısımlarda da bahsedildiği gibi yöre halkının turizm ve turistlerle entegre olmuş bir hayatı yaşadıkları görülmüştür. Kale etrafındaki birçok konutunda alternatif yerleşim birimi olan "yeni yerleşim" bölgesine taşınması da beldeden çok uzaklaşmalarını engelleyen bir durum olmuştur. Ait hissetmelerine ve herhangi bir baskı hissetmemelerine rağmen çevrede tüm komşularının evlerinin satılıp otele dönüşmesiyle komşuluk ilişkilerinin yok oluşu, mahalle kavramının yitirilmesi, eskisi gibi güvenli bir ortamı bulamadıklarını dile getirerek, yer değiştirme baskısının başka bir forma dönüştüğü görülmüştür. Bu anlamda halen kale etrafında yaşayan konut sakinlerinin, yaşam koşullarını günün şartlarına göre düzenlemelerine rağmen eskiye özlem duydukları sonucuna ulaşılmıştır.

Yapılan görüşmelerle ve yerinde gözlemlerle soylulaşmanın tetikleyici yerel bazı dinamikleri olduğunu ve bu dinamikler aracılığıyla soylulaşma sürecinin bölgeye hem olumluluk hem de olumsuzluk getirebileceği saptanmıştır (Tablo 1). Bu bağlamda Uçhisar beldesi üzerinden soylulaşmayı engelleyen ve tetikleyen yerel dinamiklerin turizmle beraber gelişime aç1lan başka bölgeler için örnek teşkil etmesi ve oluşumunun engellenerek toplumsal sorunların engellenmesi öngörülmüştür. 
Tablo 1. Uçhisar için soylulaştırma dinamikleri

\begin{tabular}{|c|c|}
\hline & Soylulaşma sürecini etkileyen yerel dinamikler (Engelleyen $(-)$, tetikleyen $(+)$ ) \\
\hline \multirow{5}{*}{ 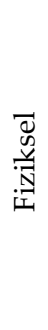 } & Kurumsal müdahale yerine bireysel yaklaşımlar (-) \\
\hline & $\begin{array}{l}\text { Tekil müdahalelerin, çevre yapıların da dönüşümüne sebep olacak etkide ol- } \\
\text { ması (+) }\end{array}$ \\
\hline & Tarihi doku (-) \\
\hline & Turist sınıfının arz- talep ve talepleri (+) \\
\hline & Kamusallık (-) \\
\hline \multirow{3}{*}{$\begin{array}{l}\bar{\pi} \\
\text { के } \\
\text { के }\end{array}$} & Aidiyet (-) \\
\hline & Fonksiyon değişimine yerel halkın desteği (-) \\
\hline & $\begin{array}{l}\text { Yeni yerleşim yerinin yakınlığı sebebiyle belirgin nüfus değişimlerinin olma- } \\
\text { ması ve yerinden etme durumunun kısmen yaşanmaması (-) }\end{array}$ \\
\hline
\end{tabular}

\section{Sonuç}

Günümüzde tarihi değer taşıyan bölgelerin turizmin ve kentsel politikaların etkisiyle yaşam kalitesi yüksek mekanların oluşturulmasının bir sonucu olarak ortaya çıkan kentsel kullanımların kullanıcı gruplarının tamamına hitap etmediği ve bazı sınıfsal gerilim noktaların oluştuğu görülmüştür. Bu gerilimlerin çoğu zaman alt grupların yerinden edilmesiyle sonuçlandığı durum soylulaştırma olarak tanımlanmaktadır. Uçhisar beldesi bahsi geçen yeni yaşam modelini yaşayan ancak içinde "yer değiştirme" sürecinin kısmen engellenebildiği bir bölge olarak analiz edilmiştir. Turizmle beraber gelen değişim/dönüşümün oluşturduğu soylulaşma sürecinin nasıl başladığı ya da engellenebileceğini yerel dinamikler ekseninde Uçhisar beldesi üzerinden araştıran çalışmada, bazı parametrelerin bu süreçte önemli dönüm noktaları olduğu ortaya çıkmıştır. Bu parametreler yerel bağlamsallığı ortaya çıkaran ve akademik yazımda soylulaştırmanın yalnızca yerinden etme ve sınıf farklılaşması durumu ile sınırlanan anlamına farklı bir bakışla yaklaşılması gerekliliğini ortaya çıkarmıştır. Tarihi dokunun korunması, sayıca artan otel işletmelerine rağmen kamusallığın bozulmayışı, turizmle yerli halkın bütünleşmesi, yeni-eski yerleşimin gündelik hayatta zıtlaşan yaşam modeli ortaya çıkarmasından ziyade istihdam imkânı sunması ve turist- yerli ilişkisinin pekiştirilmesi, Uçhisar için soylulaşma sürecinde etkisi olan yerel dinamikleri oluştur- 
muştur. Bunun yanında soylulaştırmanın bir katkısı olarak fiziksel yenilenmenin, yapıların üst gelir grubu tarafından kullanılır/işletilir hale getirilmesiyle bir soylulaştırma sürecini de başlattığı gözlenmektedir. Bu anlamda soylulaştırmanın kentlerde ya da kent parçalarında ne kadar ince bir çizgide var olduğu ortadadır. Bu nedenle çoğunlukla kentsel ölçekte büyük yatırımların sonucunda ortaya çıktığı görülen soylulaşmanın, gelişim sürecinde olan kırsal bölgelerde tarihi doku, geçici sınıflar, kamusallık, aidiyet, gündelik yaşam pratikler gibi kentsel gelişimin önemli başlıklarıyla değişen yerel dinamiklerin tetiklediği ve etkilediği farklı bir "soylulaştırma" kavramını ortaya çıkardığı sonucuna varılmıştır.

Son olarak bir ön araştırma niteliğinde olan bu çalışma, bu tür soylulaşma izlerinin görülebileceği bölgeler için yerel bağlamsallığın değerlendirilmesi gereken bir alan olarak ortaya çıktığını ve çok boyutlu bir kavramsallaştırmanın gerekli olduğunu göstermiştir. 


\title{
Extended Abstract
}

\section{Effects of Contextualization on Gentrification: Nevşehir Uçhisar in Tourism Gentrification}

\author{
Tuğçe Utku \\ ORCID: 0000-0002-7156-6728 \\ Zeynep Uludağ \\ ORCID: 0000-0001-9242-7957
}

When academic studies are examined, it is clear that gentrification studies have gained an endless and transforming dimension in terms of both the change of the first definition until today and the effect of different building environments as a building type. This study created a discussion ground by degrading this change to the term "tourism gentrification" of Anglo-Saxon gentrification definitions. In this way, while providing a critical approach to gentrification emerging through tourism, the gentrification process has been examined through this form. One of the first studies in the gentrification literature to explain the process of tourism is Gotham's work. Gotham (2005) defines tourism gentrification as the transformation of a middle-class neighborhood into a relatively rich and elite settlement with the increase of corporate entertainment and tourism venues.

The study analyzed the effect of local dynamics on gentrification through the town of Uchisar, which has significant contributions in terms of national and international tourism in Nevşehir. Uçhisar is also one of the defensive hill settlements of the Cappadocia region. In its center, it hosts Uçhisar Castle, which has attracted much attention for tourism purposes and was lived in until the 1960s. Since the Roman period, there have been many units such as rockcut rooms, shelters, warehouses, and cisterns in this castle. It is seen that the construction of the living units in the castle and its foothill date back to ancient times and many buildings that survive today have been restored and opened to use. The study focuses on this environment and mostly examined the historical development of Uçhisar Castle and its surroundings, which is the landmark of the town. In the 1960s, the vicinity of Uçhisar Castle was declared a "disaster zone" due to the danger of the rocks collapsing, and those living on the foothill of the castle started to create a new settlement towards the south of the town. For this reason, it was stated that the surrounding of the castle was 
not only ruined, but, the residents of the new settlement took the materials of their old houses, because of the insufficiency of the opportunities provided by the state and used them in the construction of their new houses, which further increased the neglect of the area around the castle. The situation that caused the region to reach its old historical texture by removing the collapsing texture of the region from being ruined was realized with the individual interventions that came to the region as the 2000s approached. Investors bought these ruined houses and started restoration works and the story of the region's meeting with tourism emerged in these years. The restored buildings were gradually put into use for non-residential functions such as hotels, restaurants, and shops.

With the increase in the number of hotels opened recently and the number of other commercial units supporting these units, it is seen that local residents and tourism-oriented settlements have started to intertwine in the town, and not only this but the settlement has gradually become the focus of tourism. This situation is one of the important data of the study choosing this region as a field. In the study, which analyses the effect of this intertwining on gentrification process in the town with local dynamics, discussing the physical and social change with the tourism-gentrification duo through a tourism city provided important data in the evaluation of the relationship between the households and tourists in the region.

In the study, the buildings that are still used as residences between the hotels on Göreme Street, which surrounds the castle and mostly give façade to many hotels, were determined Interviews were made with those who have lived in five of the seven residences for at least 30 years. The residences were asked how many years they have lived in Uçhisar, whether they have thought of moving, why they moved around before, whether they felt any pressure in their daily lives with tourism, their ideas about the changes in this region and whether they feel belonging to the region, and their opinions about the interventions of local governments in the region. All these questions are to determine the local dynamics of the region with the opinions of the local people who have witnessed the change of the region for many years and to determine the positive / negative parameters that prevent the gentrification in this region or come with gentrification.

In the study investigating how the gentrification process created by the change / transformation that comes with tourism started or could be prevented on the axis of local dynamics through the town of Uçhisar, it was revealed that 
some parameters were important turning points in this process. These parameters revealed the necessity to approach the definition of gentrification, which reveals local contextuality and is limited only to the state of displacement in academic writing, with a different perspective. The preservation of the historical texture, the deterioration of public spaces despite the increasing number of hotel businesses, the integration of tourism and local people, the fact that the new-old settlement offers employment opportunities rather than the contrasting life model in daily life, and the reinforcement of the tourist-indigenous relationship have created local dynamics for the gentrification process for Uçhisar. Also, it is observed that physical renewal, as a contribution of gentrification, initiates a gentrification process by making the buildings available to the upper income group. For this reason, it is concluded that gentrification, which is mostly seen because of large investments in urban scale, reveals a new form of the concept of "gentrification" rather than the concept of its with important titles of urban development such as historical texture, temporary classes, publicity, belonging and daily practices in rural areas under development. Finally, this study, which is preliminary research, also showed the necessity of creating a new conceptualization for regions where such traces of gentrification can be seen since local contextuality is a title that should not be ignored.

\section{Kaynakça/References}

Clay, P. L. (1979). Neighbourhood renewal : middle-class resettlement and incumbent upgrading in American neighbourhoods. Lexington Books. MA: D.C. Health. United Kingdom. 121.

Gant, C., A. (2015) Tourism and commercial gentrification. The ideal city. Between myth and reality. RC21 Conference, Urbino: ISA. s.1-25. 30 Ekim 2020 tarihinde, https://www.rc21.org/en/wp-content/uploads/2014/12/E4-C\%C3\%B3colaGant.pdf adresinden erişildi

Gant, C., A. (2018). Struggling with the leisure class: Tourism, gentrification and displacement. Doktora Tezi. Geography and Planning Cardiff University. 28,67. https://agustincocolagant.net/wp-content/uploads/2018/02/A-Cocola-GantPhD-Thesis.pdf adresinden erişilmiştir.

Glass, R. (2010) Aspects of change. B.-S. Japonica (Der.). Gentrification Debate içinde. s.19-27. London and New York: Routledge.

Google Earth. (2020). Street view -2020- Aralık görüntüleri. 15 Aralık 2020 tarihinde https://earth.google.com/web/ adresinden erişildi.

Gotham KF. (2005) Tourism gentrification: The case of New Orleans' Vieux Carre (French Quarter). Urban Studies. 42(7), 1099-1121. Erişim adresi: https://doi.org/10.1080/00420980500120881 
Gotham,K.F. (2018) . Assessing and Advancing Research on Tourism Gentrification 30 Ekim 2020 tarihinde, https://journals.openedition.org/viatourism/2169 adresinden erişildi.

Judd D., R. (1999) Constructing the tourist bubble. D, R. Judd ve S . Fainstein (Der.). The Tourist City içinde. s.35-53. New Haven and London: Yale University Press.

Kesar, O., Deželjin, R., ve Bienenfeld, M. (2015). Tourism Gentrification in The City of Zagreb: Time For A Debate? Interdisciplinary Management Research, 11, 657-668.

Lees, L. (2003). Super-gentrification: The Case of Brooklyn Heights. New York City. Urban Studies, 40(12), 2487-2509. Erişim adresi: https://doi.org/10.1080/0042098032000136174

Ley, D. (1994). Gentrification and the politics of the new middle class. Environment and Planning D: Society and Space, 12(1), 53-74. https://doi.org/10.1068/d120053

Ley, D. (1996). The new middle class and the remaking of the central city. Oxford: Oxford University Press.

Liang Z., Bao Ji-Gang (2015) Tourism gentrification in Shenzhen, China: causes and socio-spatial consequences. Tourism Geographies, 17(3), 461-481. DOI: 10.1080/14616688.2014.1000954

Özbay, A.(2018), Yok edilen tarihi bir mahallenin, turizm bahanesiyle hayata dönüşü: 'Argos in Cappadocia' Öyküsü', A. Bekleyen ve N. Dalkılıç (Der.), Tarihi Çevrede Yapılaşma Deneyimleri içinde (s.115-141). İstanbul: Birsen Yayın.

Pérez J. (2019): The dispute over tourist cities. Tourism gentrification in the historic Centre of Palma (Majorca, Spain). Tourism Geographies, 22(1), 171,191. Doi: 10.1080/14616688.2019.1586986

Şen, B. (2005). Soylulaştırma: Kentsel mekânda yeni bir ayrışma biçimi. H. Kurtuluș (Der.). Istanbul'da Kentsel Ayrışma Mekansal Dönüşümde Farklı Boyutlar içinde., İstanbul: Bağlam Yayınları.

Shaw,K. (2008) Gentrification: What it 1s, why it 1s, and what can be done about it Geography Compass. 2. 1697-1728. https://doi.org/10.1111/j.17498198.2008.00156.x

Smith, N. (2015). Mutenalaştırma, sınır ve kentsel mekanın yeniden yapılandırılması. N. Smith, P.Williams (Der.). Kentin Mutenalaştırılması içinde. (s.29-55). İtanbul: Yordam Kitap.

Smith,N. (2006). Yeni küresellik, yeni șehircilik: Küresel Kentsel Strateji Olarak Soylulaștırma, (Çev. İlknur Urkun, İbrahim Gündoğdu), Planlama dergisi. (Orijinal eserin yayın tarihi: 2002). 2. (s.13-27). 25 Ağustos 2020 http://www.spo.org.tr/yayinlar/dergi_goster.php?kodu=63\&dergi=3 adresinden erişildi.

Uçhisar Belediyesi. (t.y). Uçhisar Tarihi. 19 Ekim 2020 tarihinde http://www.uchisar.bel.tr/uchisar/eski-uchisar/ adresinden erişilmiştir. 
Uçhisar Belediyesi. (t.y). Turizm. 19 Ekim 2020 tarihinde http://www.uchisar.bel.tr/turizm/otel-ve-pansiyonlar/ adresinden erişilmiştir.

Zukin, S. (1987). Gentrification: Culture and Capital in the Urban Core, Annual Review of Sociology. 13. 129-147. https://doi.org/10.1146/annurev.so.13.080187.001021 